\title{
SELF-CONTROL SEBAGAI PREDIKTOR TERHADAP PERILAKU AGRESIF PADA REMAJA
}

\author{
Rina Rahayu Siregar \\ Dosen Sekolah Tinggi Ilmu Psikologi Abdi Nusa Palembang, \\ Jalan Veteran No. 1 Palembang \\ Surel :rinarahayusiregar@gmail.com
}

\begin{abstract}
Self-control is one of the individual internal factors that influence aggressive behavior in adolescents. This study aims to examine the effect of self-control on aggressive behavior in adolescents. This study uses a quantitative approach with an expost facto type. The sampling technique was purposive sampling. The research subjects were adolescents who were in high school (SMA) who had a history of committing violence. This research was conducted in D.I Yogyakarta with a total sample of 52 adolescents (27 boys and 25 girls) with an age range of 15-17 years. The data technique uses a scale of aggressive behavior and a scale of self-control. The instrument validation technique uses content validation and reliability uses the Alpha Cronbach formula. The data analysis technique used simple regression analysis. The results showed that there was a significant effect of self-control on aggressive behavior with $\alpha=0.001(p<0.05)$. Therefore, it can be ignored that self-control can be aggressive behavior among adolescents
\end{abstract}

Keywords: aggressive behavior, adolescence, self-control

\begin{abstract}
Abstrak : Kontrol diri merupakan salah satu faktor internal individu yang mempengaruhi perilaku agresif pada remaja. Penelitian ini bertujuan untuk menguji pengaruh kontrol diri terhadap perilaku agresif pada remaja. Penelitian ini menggunakan pendekatan kuantitatif dengan jenis ex-post facto. Teknik pengambilan sampel dengan purposive sampling. Subjek penelitian adalah remaja yang menduduki bangku Sekolah Menengah Atas (SMA) yang memiliki riwayat melakukan tindak kekerasan. Penelitian ini dilakukan di D.I Yogyakarta dengan jumlah sampel 52 orang remaja (27 remaja laki-laki dan 25 remaja perempuan) dengan rentang usia 15-17 tahun. Teknik pengumpulan data menggunakan skala perilaku agresif dan skala kontrol diri. Teknik validasi instrument menggunakan validasi isi dan reliabilitas menggunakan rumus Alpha Cronbach. Teknik analisis data menggunakan analisis regresi sederhana. Hasil penelitian menunjukkan bahwa ada pengaruh yang signifikan kontrol diri terhadap perilaku agresif dengan $\alpha=0,001$ $(\mathrm{p}<0,05)$. Oleh karena itu, dapat disimpulkan bahwa kontrol diri dapat menjadi prediktor perilaku agresif di kalangan remaja.
\end{abstract}

Kata kunci: perilaku agresif, remaja, kontrol diri 


\section{PENDAHULUAN}

Fenomena agresi atau perilaku menyimpang pada pelajar dan remaja dewasa ini sudah sulit dikategorikan sebagai kenakalan, tetapi sudah menjuru ke perilaku jahat atau kejahatan. Masa sekarang ini perhatian ditujukan pada tingginya kekerasan yang dilakukan oleh remaja. Masa kanak-kanak akhir dan masa remaja awal merupakan masa-masa kritis yang berpengaruh terhadap kematangan (maturity), pembentukan identitas, dan untuk beberapa remaja cenderung terlihat dalam kenakalan (Arif, 2011). Menurut Sarwono (2012), salah satu masalah utama yang dihadapi oleh remaja yang berkaitan dengan perkembangan perilaku sosial yaitu keterikatan dalam sebuah kelompok pertemanan yang negatif, yang bila tidak terkontrol maka akan menimbulkan kenakalan remaja seperti perilaku agresif pada remaja.

Bandan Pusat Statistik (2017) menunjukkan angka kriminalitas remaja yang tercatat di Kepolisian meningkat, dimana resiko remaja terkena tindakan pidana dari tiga tahun sebelumnya belum ada tanda-tanda penurunan. Badan Pusat Statistik juga menunjukkan hasil yang sesuai yakni dari 200 remaja yang terdiri dari 187 remaja laki-laki dan 13 remaja perempuan dengan rentang usia 13-17 tahun melakukan perilaku agresif. Data BPS juga menerangkan dari 200 remaja yang melakukan perilaku agresif tersebut terdiri dari 16 orang berusia 13 tahun, 17 orang berusia 14 tahun, 32 orang berusia 15 tahun, 59 orang berusia 16 tahun, dan 76 orang berusia 17 tahun. Perilaku agresif yang dilakukan remaja pada awalnya berupa tawuran atau perkelahian antar teman saja, namun seiring berkembangnya zaman, sekarang perilaku agresif berkembang menjadi tindakan kriminalitas seperti pencurian, pemerkosaan, hingga sampai pembunuhan.

Awal tahun 2018, masyarakat Yogyakarta dihebohkan dengan berita tujuh anggota geng remaja ditetapkan sebagai tersangka dalam perusakan yang dilakukan di daerah Mantrijeron (Sekar, 2018 http://www.krjogja.com). Kemudian dilanjutkan berita tentang aksi klithih di Yogyakarta yang kembali meresahkan masyarakat karena merenggut korban jiwa dan dilakukan oleh segerombolan anak remaja. Klithih merupakan salah satu bentuk anarkisme segerombolan para remaja yang ingin melukai atau melumpuhkan lawannya dengan melakukan kekerasan seperti menggunakan pecahan botol, pisau, pedang samurai dan senjata lainnya. Sepanjang tahun 2018 ini banyak berita mengenai aksi klithih yang dilakukan remaja (Widiyanto, 2018 http://www.krjogja.com). Contohnya saja pada kasus pengeroyokan oleh 
segerombolan remaja yang terjadi di Bantul menewaskan Adnan Wirawan Ardiyanta (16) pelajar SMA Muhammadyah 1 Yogyakarta (Movanita, 2016 http://www.kompas.com). Kasus kekerasan yang dilakukan anak remaja pelaku klithih yang menewaskan mahasiswa UGM Dwi Ramadhani Herlangga (26) di Jalan C Simanjuntak Yogyakarta pada Kamis 7 Juni 2018 (Aditya, 2018 http://www.krjogja.com). Kasus penyerangan masal dengan melempar pecahan botol yang dilakukan tujuh orang remaja yang melukai warga Barito Gondokusuman Yogyakarta bernama Justin (16) di Jalan Plumbon Banguntapan Bantul, Sabtu 9 Juni 2018 dinihari (Sujadmiko, 2018 http://www.krjogja.com).

Berdasarkan beberapa berita tentang perilaku agresif yang dilakukan remaja diatas, mengungkapkan bahwa kondisi remaja saat ini cenderung tidak stabil dan lebih agresif karena jarang sekali memperhatikan nilai moral yang terkandung dalam setiap perbuatan yang mereka lakukan dan cenderung bebas. Lingkungan yang selalu berubah-ubah akan mengakibatkan remaja sulit bahkan tidak bisa menyesuaikan atau beradaptasi, sehingga remaja akan melakukan perilaku yang maladaptif, seperti perilaku agresif yang bisa merugikan diri sendiri maupun orang lain (Santrock, 2012). Perilaku agresif merupakan suatu luapan emosi sebagai reaksi terhadap kegagalan individu yang ditampakkan dalam bentuk pengrusakan terhadap individu lainnya atau benda dengan unsur kesengajaan yang diekspresikan dalam bentuk kata-kata (verbal) dan perilaku (non verbal). (Sudrajat, 2011). Pemicu umum dari agresi adalah ketika seseorang mengalami suatu kondisi emosi tertentu, yang biasanya terlihat adalah emosi marah. Kemarahan dapat membuat seseorang kehilangan kontrol diri dan berperilaku agresif (Sarwono, 2011).

Adapun dampak yang dihasilkan dari perilaku agresif yaitu kerugian secara fisik, mental atau psikologis yang menimbulkan bahaya seperti ancaman, ejekan, tamparan, tendangan (Byrne, 2005; Myers, 2012; Sharma, 2016). Kemudian Sharma (2016) menjelaskan lebih lanjut bahwa sosialisasi yang digunakan remaja dalam menyelesaikan masalah adalah melalui perilaku agresif dan kekerasan, yang tujuannya untuk menyebabkan kerusakan. Perilaku agresif sendiri menurut Buss dan Perry (1992) terdiri dari empat aspek yaitu 1) agresif fisik yang berupa tindakan menyakiti, mengganggu orang, memukul, menendang, mendorong, 2) agresif verbal yaitu tindakan menyakiti secara verbal (mengejek, menghina), 3) rasa marah, dan 4) sikap permusuhan. 
Ada beberapa hal yang menyebabkan perilaku agresif pada remaja, diantaranya yaitu faktor biologi, faktor keluarga (Sanni, Udoh, Okediji, Modo, \& Ezeh, 2010), sosial-kognitif, peer atau kelompok (Kumar \& Varma, 2014), akademik, guru-sekolah, dan komunitas konformitas (Palinoan, 2015). Faktor biologi berhubungan dengan faktor genetik (misalnya tempramen), masa prinatal dan mekanisme biologi. Faktor keluarga misalnya pola asuh orang tua, faktor teman sebaya misalnya karena adanya tekanan atau penolakan dari kelompok. Faktor sosial-kognitif berhubungan dengan kurang memadainya kemampuan seseorang dalam memproses informasi sosial secara tepat.

Penelitian ini mengambil sudut pandang lain dengan menempatkan kontrol diri sebagai variabel independen untuk diteliti seberapa besar pengaruhnya terhadap perilaku agresif remaja. Secara teori kontrol diri diartikan sebagai kemampuan mengontrol diri sebagai suatu kemampuan untuk menyusun, membimbing, mengatur dan mengarahkan bentuk perilaku yang membawa individu ke arah konsekuensi yang lebih positif dari sebelumnya (Ghufron \& Risnawati, 2010), atau sebagai kemampuan manusia untuk menahan dan mengendalikan perilaku sosial yang tidak pantas (DeWall, Finkel, \& Denson, 2011).

Kontrol diri sangat diperlukan bagi setiap individu khususnya remaja, jika remaja tidak mampu untuk melakukan kontrol diri dengan baik, maka remaja dikhawatirkan dapat mengalami krisis identitas, sehingga remaja memiliki kecenderungan berperilaku negatif dalam kehidupan sehari-hari (Widiarti, 2010). Hal ini didukung oleh hasil penelitian (DeWall, Finkel, \& Denson, 2012) yang menyatakan bahwa kegagalan kontrol diri dapat memberikan kontribusi untuk tindakan yang paling agresif yang menyertakan kekerasan. Penjelasan lain juga menunjukkan bahwa individu yang memiliki sifat pengendalian diri yang rendah lebih mungkin untuk terlibat dalam perilaku kriminal, dan menyimpang dibandingkan dengan mereka yang memiliki tingkat kontrol diri yang tinggi (Moon \& Alarid, 2014). Ketika munculnya perilaku agresif, kontrol diri dapat membantu seseorang merespon sesuai dengan standar pribadi atau sosial yang dapat menahan munculnya perilaku agresi (Dewall, Finkel, \& Denson, 2011).

Menurut Tangney, Baumeister, dan Boone (2004) kontrol diri merupakan pusat dari konsep pengendalian diri individu yaitu kemampuan untuk mengesampingkan atau mengubah tanggapan batin seseorang, serta 
untuk menekan kecenderungan perilaku yang tidak diinginkan dan menahan diri dari tindakan tersebut. Adapun lima aspekkontrol diri menurut Tangney, Baumeister, dan Boone (2004) yaitu 1) Penelitian ini bertujuan menguji apakah kontrol diri dapat memprediksi perilaku agresif pada remaja. Pentingnya melakukan penelitian ini adalah untuk melihat gambaran psikologis remaja yang melakukan perilaku agresif. berdasarkan kajian literature dan penelitian sebelumnya, hipotesis peneliian ini adalah konrol diri dapat memprediksi perilaku agresif remaja.

\section{METODOLOGI PENELITIAN}

Penelitian ini menggunakan pendekatan kuantitatif dengan jenis penelitian ex-post facto. Penelitian ini dilakukan di Kota Yogyakarta Populasi dalam penelitian ini yaitu anak remaja usia 15-18 tahun yang menduduki bangku sekolah. Teknik pengambilan sampel yang digunakan adalah purposive sampling. Peneliti menentukan sampel berdasarkan karakteristik tertentu. Subjek dalam penelitian ini sebanyak 52 orang remaja (27 orang remaja laki-laki dan 25 orang remaja perempuan) yang berusia 15-17 tahun, yang tergabung dalam Sekolah Menengah Atas. Instrument penelitian ini menggunakan dua skala, disiplin diri, 2) tindakan yang tidak implusif, 3) pola hidup sehat, 4) etika kerja / menilai kemampuan diri, dan 5) reliabilitas.

skala pertama adalah skala Aggression Questionnaire

diadaptasi dari Buss dan Perry (1992) dengan 4 aspek yang mewakili empat sub skala yaitu agresif fisik, agresif verbal, rasa marah, dan sikap permusuhan. Skala kedua menggunakan skala kontrol diri yang diadaptasi dari Tangney, Baumeister, dan Boone (2004) dengan 5 yang mewakili lima sub skala yaitu disiplin diri, tindakan atau aksi yang tidak implusif, pola hidup sehat, etika kerja, dan reliabilitas.

Teknik validitas menggunakan validitas isi dan konsistensi internal serta reliabilitasnya menggunakan teknik Alpha Cronbach. Selanjutnya, data dianalisis dengan mengunakan teknik regresi sederhana. Instrumen perilaku agresif yang digunakan memiliki koefisien reliabilitas Alpha Cronbach sebesar 0,862 dan terdiri dari 12 butir pernyataan. Selanjutnya, instrumen kontrol diri yang digunakan dalam penelitian ini memiliki koefisien reliabilitas Alpha Cronbach sebesar 0,780 dan terdiri dari 36 butir pernyataan

\section{HASIL DAN PEMBAHASAN}

Pada Tabel 1 menunjukkan deskriptif statistik yang memuat nilai rata-rata (mean), 
standar deviasi dan jumlah pada tiap variabel. Berdasarkan Tabel 1 adapun perbandingan nilai perilaku agresif lebih rendah $(\mathrm{m}=34,92, \mathrm{SD}=6,939$ dan $\mathrm{N}=52)$ dibandingkan dengan nilai kontrol diri $(\mathrm{m}=$ $58,67, \mathrm{SD}=8,198$, dan $\mathrm{N}=52$ )

Tabel 1. Statistik Variabel

\begin{tabular}{lccc}
\hline & N & Mean & Std. Deviation \\
\hline Perilaku_Agresif & 52 & 34.92 & 6.939 \\
\hline Kontrol_Diri & 52 & 58.67 & 8.198 \\
\hline Valid N (listwise) & 52 & &
\end{tabular}

Pada Tabel 2 menunjukkan persamaan regresi $\mathrm{Y}=44,943-0,171 \mathrm{X}$. Nilai minus yang didapatkan menunjukkan hasil negatif, dimana bahwa setiap penurunan skor sebesar 1 variabel kontrol diri, akan dapat meningkatkan skor sebesar -0,171 pada perilaku agresif, artinya semakin tinggi skor kontrol diri, maka semakin rendah tingkat perilaku agresif. hal tersebut juga menunjukkan bahwa kontrol diri dapat digunakan untuk memprediksi perilaku agresif dengan nilai $\mathrm{t}$ hitung $-2,457>\mathrm{t}$ tabel 2.006647, sehingga dapat disimpulkan hipotesis diterima yang berarti bahwa kontrol diri dapat digunakan sebagai prediktor perilaku agresif.

Tabel 2. Coefficients ${ }^{a}$

\begin{tabular}{|c|c|c|c|c|c|}
\hline \multirow[b]{2}{*}{ Model } & \multicolumn{2}{|c|}{$\begin{array}{l}\text { Unstandardized } \\
\text { Coefficients }\end{array}$} & \multirow{2}{*}{$\begin{array}{c}\begin{array}{c}\text { Standardized } \\
\text { Coefficients }\end{array} \\
\text { Beta } \\
\end{array}$} & \multirow[b]{2}{*}{$\mathrm{t}$} & \multirow[b]{2}{*}{ Sig. } \\
\hline & $\mathrm{B}$ & Std. Error & & & \\
\hline & 44.943 & 6.945 & & 6.472 & .000 \\
\hline Kontrol_Diri & -.171 & .117 & -.202 & -2.457 & .001 \\
\hline
\end{tabular}

a. Dependent Variable: Perilaku_Agresif

Pada Tabel 3 memaparkan hasil analisis regresi bahwa signifikansi kontrol diri terhadap perilaku agresif adalah $\mathrm{F}=$
5,121 dengan $\alpha=0,001 \quad(p<0,05)$, yang artinya kontrol diri dapat memprediksi perilaku agresif remaja. 
Tabel 3. ANOVA

\begin{tabular}{|c|c|c|c|c|c|}
\hline Model & Sum of Squares & df & Mean Square & $\mathrm{F}$ & Sig. \\
\hline Regression & 99.954 & 1 & 99.954 & 5.121 & $.001^{\mathrm{b}}$ \\
\hline Residual & 2355.739 & 50 & 47.115 & & \\
\hline Total & 2455.692 & 51 & & & \\
\hline \multicolumn{6}{|c|}{ a. Dependent Variable: Perilaku_Agresif } \\
\hline
\end{tabular}

Pada Tabel 4 menunjukkan besarnya konribusi variabel kontrol diri terhadap perilaku agresif yaitu R Square $=0,091$, yang artinya kontrol diri hanya berkontribusi terhadap perilaku agresif sebesar 9,1\%, dan sisanya dipengaruhi faktor lain yang tidak diteliti dalam penelitian ini.

Tabel 4. Model Summary

\begin{tabular}{|c|c|c|c|c|}
\hline Model & $\mathrm{R}$ & $\begin{array}{c}\mathrm{R} \\
\text { Square }\end{array}$ & $\begin{array}{c}\text { Adjusted R } \\
\text { Square }\end{array}$ & $\begin{array}{l}\text { Std. Error of } \\
\text { the Estimate }\end{array}$ \\
\hline 1 & $.202^{\mathrm{a}}$ & .091 & .022 & 6.864 \\
\hline
\end{tabular}

Berdasarkan hasil penelitian yang dilakukan, analisis data menunjukkan bahwa terdapat pengaruh signifikan dari variabel kontrol diri terhadap variabel perilaku agresif sebesar 9,1\%, sedangkan sisanya sebesar 90,9\% dipengaruhi oleh faktor-faktor lain. Hal ini menunjukkan bahwa kontrol diri dapat digunakan sebgai prediktor dalam menurunkan tingkat perilaku agresif. Tingkat kenaikan nilai pada kontrol diri akan diikuti penurunan nilai pada perilaku agresif yang ditunjukkan dengan persamaan $\mathrm{Y}=44,943-0,171 \mathrm{X}$, adapun tanda negatif semakin baik kontrol diri yang dimiliki remaja, maka semakin rendah perilaku agresif, begitupun sebaliknya. Adapun
(-) pada nilai -0,171 menunjukkan arah berbanding terbalik antara kedua variabel, artinya semakin tinggi skor kontrol diri, maka semakin rendah tingkat perilaku agresif. Begitu pula sebaliknya, semakin rendah skor konrol diri, maka semakin tinggi pula tingkat perilaku agresif remaja.

Hasil penelitian ini sejalan dengan hasil penelitian yang dilakukan Auliyah dan Nurwidawati (2014) yang menunjukkan terdapat pengaruh negatif yang signifikan antara kontrol diri terhadap perilaku agresif. Artinya perilaku agresif yaitu keinginan untuk menyerang segala sesuatu yang dianggap sebagai penghambat baginya. Salah satu 
upaya untuk mencegah perilaku agresif remaja yaitu dengan mengontrol diri. Remaja yang mempunyai kontrol diri tinggi mampu mengubah kejadian dan menjadi agen utama dalam mengarahkan dan mengatur perilaku, sehingga membawa kepada konsekuensi positif.

Penelitian menunjukkan bahwa individu yang memiliki skor lebih tinggi pada sifat pengendalian diri cenderung lebih sadar dan menunjukkan kecenderungan yang lebih besar untuk memberikan sanksi terhadap perilaku merusak diri sendiri dan impulsif (Vohs \& Baumeister, 2004). Mereka menunjukkan pengambilan perspektif yang unggul dan kemampuan untuk mempertahankan hubungan yang sehat dengan orang lain karena mereka cenderung lebih sadar akan pikiran dan tindakan mereka sendiri dan orang lain dan dampak dari pikiran dan tindakan ini pada diri mereka sendiri dan orang lain (Tangney, Baumeister, \& Boone, 2004). Selain itu, orang dengan tingkat kontrol diri yang lebih besar lebih adil dan dapat dipercaya dan cenderung mengalami lebih banyak rasa bersalah daripada orang lain. Hal ini sejalan dengan penelitian yang dilakukan Denson, DeWall, Finkel (2012) menunjukkan bahwa kegagalan pengendalian diri sering memprediksi agresi dan, sebaliknya, memperkuat kontrol diri mengurangi agresi.
Dari penjelasan diatas, maka dapat disimpulkan bahwa kontrol diri memiliki hubungan yang positif terhadap perilaku agresif yang dilakukan remaja, sehingga dapat dikatakan bahwa variabel kontrol diri merupakan prediktor yang dapat mempengaruhi perilaku agresif pada remaja..

\section{SIMPULAN}

Kesimpulan yang dapat diambil dari analisis data penelitian yang telah dilaksanakan adalah terdapat pengaruh signifikan yang positif berdasarkan hasil persamaan regresi antara variabel interaksi sosial online dan variabel kecemasan sosial secara bersama-sama terhadap kecanduan internet pada remaja dengan besarnya pengaruh $33,7 \%$ dan sisanya dipengaruhi oleh variabel lain. 


\section{DAFTAR RUJUKAN}

(APJII), A. P. J. I. I. (2019). Hasil Survei Penetrasi dan Perilaku Pengguna Internet Indonesia 2018. Retrieved from https://apjii.or.id/survei

Crutzen, R., de Nooijer, J., Brouwer, W., Oenema, A., Brug, J., \& de Vries, N. K. (2011). Strategies to facilitate exposure to internet-delivered health behavior change interventions aimed at adolescents or young adults: a systematic review. Health Education \& Behavior, 38(1), 49-62.

Fonseca, C. (2015). A Parent's Guide to Social Anxiety Raising the Shy Child Advice for Helping Kids Make Friends, Speak Up, and Stop Worrying. Waco, Texas, USA: Prufrock Press Inc.

Huang, H. (2014). Social Media Generation in Urban China. New York Dordrecht London: Springer Publishing Company.

Kuss, D. J., Van Rooij, A. J., Shorter, G. W., Griffiths, M. D., \& van de Mheen, D. (2013). Internet addiction in adolescents: Prevalence and risk factors. Computers in Human Behavior, 29(5), 1987-1996.

Lee, Y.-H., Ko, C.-H., \& Chou, C. (2015). Re-visiting Internet addiction among Taiwanese students: A cross-sectional comparison of students' expectations, online gaming, and online social interaction. Journal of Abnormal Child Psychology, 43(3), 589-599.

Lee, Y.-H., \& Wu, J.-Y. (2013). The indirect effects of online social entertainment and information seeking activities on reading literacy. Computers \& Education, 67, 168-177.

Lee, Z. W.-Y., \& Cheung, C. M.-K. (2014). Problematic use of social networking sites: The role of self-esteem. 48(2), 381.

Tao, R., Huang, X., Wang, J., Zhang, H.,
International Journal of Business and Information, 9(2).

Merikangas, K. R., He, J., Burstein, M., Swanson, S. A., Avenevoli, S., Cui, L., ... Swendsen, J. (2010). Lifetime prevalence of mental disorders in US adolescents: results from the National Comorbidity Survey Replication-Adolescent Supplement (NCS-A). Journal of the American Academy of Child \& Adolescent Psychiatry, 49(10), 980-989.

Morahan-Martin, J., \& Schumacher, P. (2003). Loneliness and social uses of the Internet. Computers in Human Behavior, 19(6), 659-671.

Musetti, A., Cattivelli, R., Giacobbi, M., Zuglian, P., Ceccarini, M., Capelli, F., ... Castelnuovo, G. (2016). Challenges in internet addiction disorder: is a diagnosis feasible or not? Frontiers in Psychology, 7, 842.

Nakaya, A. C. (2015). Internet and Social Media Addiction. San Diego, United States of America: Reference Point Press.

Norris, M. L. (2007). HEADSS up: Adolescents and the Internet. Paediatrics \& Child Health, 12(3), 211-216.

Perdew, L. (2014). Internet addiction. North Mankato, Minnesota, United States of America: Abdo Publishing.

Shaw, M., \& Black, D. W. (2008). Internet addiction. CNS Drugs, 22(5), 353-365.

Smahel, D., Brown, B. B., \& Blinka, L. (2012). Associations between online friendship and Internet addiction among adolescents and emerging adults. Developmental Psychology, Zhang, Y., \& Li, M. (2010). Proposed diagnostic criteria for 
internet addiction. Addiction, 105(3), 556-564.

Wulandari, R. (2015). hubungan antara kontrol diri dengan kecanduan game online pada remaja di warnet lorong Cempaka dalam kelurahan 26 Ilir Palembang. Jurnal Fakultas Psikologi Universitas Bina Darma Palembang.

Young, Kimberly S, \& Rogers, R. C. (1998). The relationship between depression and Internet addiction. Cyberpsychology \& Behavior, 1(1), 25-28.

Zhang, H., Li, D., \& Li, X. (2015). Temperament and problematic Internet use in adolescents: A moderated mediation model of maladaptive cognition and parenting styles. Journal of Child and Family Studies, 24(7), 1886-18 
